\title{
EMPLOYMENT OF ADOLESCENTS AND CHILDREN IN THE ASPECT OF POLISH EDUCATIONAL REFORM - CHOSEN LEGAL PROBLEMS
}

\author{
Milena Kloczkowska*
}

\begin{abstract}
The employment of adolescents is an extremely important phenomenon, although doctrine rarely discusses it. This solution enables young people to gain qualifications early and promises long and successful cooperation for the employer. It should be remembered, however, that at such a young age the most important sphere of life is not work, but education and appropriate psycho-physical development. Bearing in mind the delicacy of children and adolescents, it is necessary to create legal constructions which will protect young people from too early collision with problems connected with work such as: stress, exhaustion, and pressure.

The notion of adolescence is constantly intertwined with the notion of child and it is not easy to judge when these terms are used. This article intends to discuss these terms, and to present them through the applicable laws. In addition, the article presents research on the employment of adolescents and children in Poland based on reports from the National Labour Inspectorate.

The legislator had a difficult task - to create appropriate regulations which would not only make work possible, but at the same time properly secure the already mentioned most important spheres of life of adolescents and children. This task undoubtedly becomes even more difficult when the change of other legal acts forces a rush to regulate such a delicate legal sphere. The aim of this article is

* Milena Kloczkowska, M.A., Teaching Associate, Department of Labour and Social Insurance Law, Faculty of Law, Canon Law and Administration, The John Paul II Catholic University of Lublin, correspondence address: Al. Racławickie 14, 20-950 Lublin, Poland; e-mail: milena.kloczkowska@kul.pl; https://orcid.org/0000-0003-2660-9415.
\end{abstract}


to present advantages and disadvantages of current legal constructions based on the analysis of regulations and statistics.

Keywords: adolescents, children, child employee, adolescent, worker

\section{INTRODUCTION}

The subject of performed research is Polish legislation referring to adolescents and children currently in force. It is a vast matter but above all it is very sensitive, thus it requires a diligent analysis and an objective, interdisciplinary approach.

In the report "Global estimates of child labour 2012-2016" The International Labour Organisation has estimated that in 2016 there were 218.0 million children between the ages of 5 and 17 years old worldwide. Of all children aged 5-14 employed worldwide, about 53.3\% are in Africa, 36.6\% in Asia Pacific, 6.5\% in America, 2.8\% in Europe and Central Asia, and $0.7 \%$ are in Arab countries ${ }^{1}$. In Europe and Central Asia, as many as $76.6 \%$ of the working children in the region work in agriculture. ${ }^{2}$

Child labour is not always in fact a compulsory phenomenonmore than once it turns out to be a manifestation of human maturity and self-discipline of a young person who tries to achieve independence and shape responsibility through taking consequences for own actions while earning money. There are also many negative sides to child labour. When the burden is excessive, it has a negative impact on their physical and mental health. Less physical fitness, immaturity and lack of ability to predict the consequences result in accidents ${ }^{3}$. Violence, coercion and punishment have often been used to mobilise children to work, resulting in anxiety and depression. Many times during such work, children are exposed to the influence of very strong emotions related, for example to

1 International Labour Office, Global estimates of child labour, 2012-2016, Geneva 2017, accessed December 18, 2020, https://www.ilo.org/wcmsp5/groups/public/---ed_ norm/---ipec/documents/publication/wcms_586125.pdf.

2 Ibidem.

3 Stanisław Lachowski, Praca dzieci wiejskich a ich rozwój fizyczny i stan zdrowia (Lublin: IMW, 1999), 15. 
slaughtering their favorite animal ${ }^{4}$. Work also negatively affects the social aspect of the child, because he or she is repeatedly deprived of childhood, time to develop interests, carelessness, while burdening him with excessive duties. ${ }^{5}$

A young person is defined in the legislation as a child or an adolescent in reference to age, not only because of a lack of a proper permissions for taking independent decisions and actions emerging from certain legal effects but mainly for psycho-physical maturity which stays in a process of dynamic evolution as to a particular age defined by the legislator. To not to put it under psychologists or behaviourists criticism, it should be said that the applied threshold is a census only for a legislative reference and does not evaluate mental and physical qualities.

Certain changes referring to legal aspects of working children and adolescents in the Polish legislation were made in recent years. They caused many interpretational disputes that refer to definition of an adolescent, among others. This article tries to answer questions that arose during interpretation of new legal rules which refer to workers under 18 years old not only from labour law perspective but also more widely, in a matter of protection of them under constitutional law. A starting point for effective understanding of this legal aspect is a constitutional model definition in a matter of citizens rights and freedoms of these persons, including the right to work.

\section{CHILD AS A LEGAL TERM}

The term 'child' is not defined in Polish legislation. Art. 70 par. 1 of the Polish Constitution from April $21997^{6}$ establishes a responsibility for education until 18 years old, in art. 62 par. 1 it gives the active voting right after achieving 18 years old, and in art. 65 par. 3 forbids full time employ-

\footnotetext{
4 Ibidem, 16.

5 Ibidem, 16.

6 The Constitution of the Republic of Poland, Journal of Laws 1997, No. 78, item 483, as amended.
} 
ment of children until being 16 years old. It should then be claimed, that a child is a person below 18 years of age. ${ }^{7}$

The age limit that is written in the Constitution is explicitly stated in art. 1 of the Convention on the Rights of the Child of the United Nations ${ }^{8}$ that was ratified by Poland July 7 1991. According to this article, a child is any person that is under the age of 18 years, unless achieving majority earlier- this implies a consent between international and national law. A correlation with positive national law.

There is a connected concept of the 'welfare of the child' with the term 'child' in the legislation. Definition of the child itself does give a possibility for understanding of a subject matter of rights, and every other regulation referring to it. Taking into consideration the way of forming of norms in the Convention the term child is not the key for creation of norms but its welfare. In art. 3 par. 2 of the Convention there was implemented a rule according to which parties act to provide protection and care for a child in a way that is required for its own good when taking into consideration rights and obligations of parents, legal guardians or other persons legally responsible for them, who should take every necessary step, both legislative and administrative. ${ }^{?}$

There are no 'welfare of the child' attributes in the Polish Constitution. Such considerations were severally raised by the Constitutional Tribunal of Poland. In the case K18/02 from April 282003 the Tribunal stated that "Constitution (...) does not define on its own elements of the welfare of the child. (...) the welfare of the child is a general constitutional clause, which reconstruction should be done in reference to constitutional axiology and general assumptions of the system. "10' It seems that the clause 'welfare of the child' is a classical clause of the first type. As such, it consists within itself a right for a legislative body to perform, basing on criteria that are outside of the law indi-

7 Elżbieta Hanna Morawska, "Ochrona praw dziecka w świetle art. 72 Konstytucji RP: uwagi na tle orzecznictwa Trybunału Konstytucyjnego,” Kwartalnik Prawa Publicznego 7 , no. 4 (2007): 127.

8 United Nations General Assembly Convention on the Rights of the Child of 20 November 1989 Journal of Laws 1991, No. 120, item 526.

9 Ibidem.

10 Polish Constitutional Tribunal, Judgment of 28 April 2003, Ref. No. K 18/02, Journal of Laws 2003, No. 83 item 772. 
vidual evaluation in reference to specific situation. In other words, for the first type clause a body that applies a law is authorised to decide about a legal problem depending on evaluation of the situation that appears in a particular case. Then, it is an individual evaluation in aspect of which a body that applies that law may take into consideration common views in reference to what acts for good and what not for the 'welfare of the child', in example but that decision is case-by-case dependent". "It is without prejudice to the principle of proportionality that the best interests of the child should be a guiding principle of the Constitution and family law, which lies at the heart of all regulations concerning the child, as well as court rulings and decisions interfering with his or her essential interests. "12 "The 'Welfare of the child' is a core for all rules referring to a child's rights. It is an instrument for binding norms interpretation and a directive for lawmaking and application of a law, a standard for decision making process in child cases and for settlement of collisions of a child and other persons rights, parents especially."

Both above mentioned terms- the child and its welfare act together and inseparably and only in this set are fundamental for the lawmaking process that provides protection of rights of a child. The protection is determined in two levels, theoretical which links with the subject matter of a child, and factual which is shaped through application of these rights. There is an important assumption that rights of a child belong to human rights group which is underlined by placement, form and significance of provisions referring to children in the Constitution.

\section{CHILD AS A CITIZEN IN THE CONSTITUTION}

The Constitution of the Polish Republic, as the supreme legal act is the basis for the State's regime. It sets rules according to which all legal

11 Morawska, "Ochrona praw dziecka," 131-132.

12 Polish Constitutional Tribunal, Judgment of 27 May 2002, Ref. No. K 20/01, Journal of Laws 2002, No. 78, item. 716, also Polish Supreme Court, Judgment of 11 October 2013, Ref. No. I CSK 697/12, unreported.

13 Por. Mirosław Baum and Wanda Stojanowska, Wtadza rodzicielska pozamatżeńskiego i rozwiedzionego ojca. Studium socjologiczno-prawne (Warsaw: Akademia Pedagogiki Specjalnej im. Marii Grzegorzewskiej, 2000), 32. 
acts in Poland are created. It is a guarantor for many rights and freedoms under presented the articles, and points special attention on a child and its protection. It happens in alignment with International Acts that are observed in the Polish legal system. Many articles of the Supreme Act pay attention to children and families by establishment of institutions that guarantee them special help and protection. It determines rules for inferior regulations whose goal is to normalize every aspects of general provisions from the Constitution.

The Constitution implements fundamental legal rules for organization of legal order that takes into consideration rights and freedoms of an individual. According to the International Law, a child is a human until the age of $18 .{ }^{14}$ Polish law lacks a definition of a child, and because of that the International Legal definition is applicable.

Source for all rights is a dignity that is described in art. 30 of the Constitution. It is inborn, inalienable and creates a source for freedoms and rights for a human and citizen. It is inviolable and its observation is obligatory for public authorities. ${ }^{15}$ According to the Tribunal evaluation, the dignity itself is "(...) a level of reference for a value system, around which the Constitution was built and the legal order in the Country as a whole at the same time." ${ }^{16}$ The dignity then, is a basic element of the whole system of Constitutional rights and freedoms.

According to article 34 paragraph 1 of the Constitution 'Polish citizenship shall be acquired by birth to parents being Polish citizens. Other methods of acquiring Polish citizenship shall be specified by statute ${ }^{17}$, so a child becomes a citizen in the moment of being born. It needs to be noticed that children as other natural persons that are under Polish Republic authority use rights provided in the Constitution under art. 37 par.1. In the case P12/99 the Tribunal noticed that, according to international standards,

14 United Nations General Assembly Convention on the Rights of the Child of 20 November 1989 Journal of Laws 1991, No. 120, item 526.

15 The Constitution of the Republic of Poland, Journal of Laws 1997, No. 78, item 483, as amended.

16 Polish Constitutional Tribunal, Judgment of 4 April 2001, Ref. No. K 11/00, Journal of Laws 2001, No. 32 item 386.

17 The Constitution of the Republic of Poland, Journal of Laws 1997, No. 78, item 483, as amended. 
meaning of the term 'being under Polish Republic authority' needs to be considered under a territorial aspect, including exceptions. According to that, for protection of rights of a child on the basis of the Constitution a requirement for having Polish citizenship by that child does not matter, however there are some Constitution based exceptions to that. ${ }^{18}$

The Polish Constitution covers rights and freedoms catalogue and rights of children which are treated particularly. Basic regulation, having significant meaning in shaping the rights of a child, is pointed in the doctrine art. 72 of the Constitution which provides a basic guaranty of those rights. In literature of the subject a discussion is present not only about tasks or responsibilities of public authorities (...) and even not about the State responsibilities but about the Polish Republic. "It needs to be linked with a gravity that the Constitution creators stressed for problems of children." 19

Art. 72 of the Constitution imposes a responsibility on Poland to provide protection of the rights of a child, and it requires an immediate action in case of emergence of a threat for that rights. Fulfillment of the responsibility from paragraph 1 must be in accordance with fundamental principles of the Constitution that are included in the rights and freedoms catalogue. In that case, it links directly with the proportionality principle which refers to all rights and freedoms from the catalogue, and this implicates rights and freedoms of a child. ${ }^{20}$ That rule sets limitations between intervention of authorities in family life, personal and private area. Requirements that are an instruction for proportionality preservation are included in art. 31 par. 1 of the Constitution. ${ }^{21}$ Constitutional law doctrine pays attention on proportionality application for establishment of limitations which are to be a determining level of State intervention. Firstly, "limitations of rights and freedoms of a child may be set only in a way of a statute (...). Secondly, they may be set if they are 'necessary in a democratic state', for protection of a public

18 Piotr Winczorek, Komentarz do Konstytucji RP z dnia 2 kwietnia 1997 r. (Warsaw: Liber, 2000), 96.

19 Winczorek, Komentarz, 96.

20 Polish Constitutional Tribunal, Judgment of 15 November 2000, Ref. No. P 12/99, Journal of Laws 2000, No. 100, item 1085.

21 The Constitution of the Republic of Poland, Journal of Laws 1997, No. 78, item 483, as amended. 
interest which is set in protection of such values as: public security, public order, natural environment, public health, public morality, and freedoms and rights of other persons. Also, violation of proportionality rule is to be evaluated under three criteria which are, a degree of utility of such restrictions for performance of a target for which they were dedicated, then under necessity that is understand as an obligation of necessity for setting such restrictions for a protection of a public interest that they are linked with, and finally through proportionality in a strict sense which means preservation of a correct proportion between effects of implemented regulation and burdens that are implemented on a citizen due to that. ${ }^{\prime 22}$. The Tribunal in the verdict from January 12, 2000 P 11/98 took a voice for a problem of setting limitations of rights and freedoms of a child pointing that a target for covering that topic is an answer for a question whether "'the same target (effect) was not possible to be achieved by using different restrictions, less harmful to a citizen because less (much lower) intervening with one's rights and freedoms. "23

Art. 72 par. 1 first sentence of the Constitution points clearly that the State has a responsibility to provide a protection to all children without any limitations. To gather data in that aspect, it is necessary to check the above mentioned Convention on the Rights of the Child. The second sentence of this article shifts it as "beyond level", i.e. it indicates that due to the nature, physical and mental development of a child, as well as the inability to cope with themselves, all children, without exceptions are subject to appropriate protection, in the same manner as every human being, without exclusion to parents or public authorities "(...) has a right to demand from public legal authorities protection of a child against violence, cruelty, exploitation and demoralisation.". ${ }^{24}$ Paragraph 2 of the mentioned article is a continuation of that thought and general assumptions in that matter but it refers to obligation to provide care and help to children that were deprived of parental care, by public authorities. Now, attention should be paid on subjects which are mentioned in the articles. They are

22 Morawska, “Ochrona praw dziecka," 129.

23 Polish Constitutional Tribunal, Judgment of 12 January 2000, Ref. No. P 11/98, Journal of Laws 2000, No. 3, item 46.

24 The Constitution of the Republic of Poland, Journal of Laws 1997, No. 78, item 483, as amended. 
two in each case: a child and public legal authorities. A doctrine separates them significantly on primary subject which is a child because for its protection these regulations were created, and secondary subject that are public legal authorities which must implement these rules according to their destination. ${ }^{25}$ "Constitution-maker treating a child as a subject sets according to that an imposition directed to public legal authorities and persons responsible for a child. ${ }^{26}$ Art. 72 par. 4 of the Constitution obliges public legal authorities to appoint a Children's Ombudsman. On the power of the Constitution this body is raised to the rank of Constitutional bodies, which means that it is fundamental. It is worth noticing that it is the highest body in a rank dedicated to protection of children's rights only.

Pursuant to article 65 par. 3 of the Constitution there was implemented a prohibition for full time employment of children under 16 years of age. This rule is a guaranty for protection of rights of children that stems from art. 72 of the Constitution, and in this case against economic exploitation mainly. According to the Constitution, it does not require to achieve majority for full legal rights to be employed full time during a moment of being 18 years old. The only condition is age.

\section{ADOLESCENT AS A WORKER IN POLISH LABOUR LAW}

Until amendmens from 2017 there was a model of education system from September 11999 that created primary, middle and high schools. ${ }^{27}$ In reference to present changes, there is a need to cover also the previous system before 1999 when the education system observed eight classes of primary school and no middle school. At that time, The Labour Code in Section IX, prohibited employment of persons below 16 years old, and for the people who fulfilled this condition it was possible after finishing primary school, with some exceptions included.

25 Ibidem.

26 Stanisław Stadniczeńko, "Ochrona praw dziecka wynikająca z art. 19 Konwencji o prawach dziecka oraz art. 72 Konstytucji RP,” Zeszyty Naukowe Państwowej Wyższej Szkoty Zawodowej im. Witelona w Legnicy, no. 22(1) (2017): 16.

27 Act of 7 September 1991 on the education system Journal of Laws 1991, No. 95, item 425, as amended. 
The Constitution in art. 65 par. 3 clearly establishes that it is forbidden to employ children under age 16 , and points that a proper regulation will set forms and a character of employment. It was discussed in doctrine, whether a regulation should cover exceptions from full time employment or cases where part time employment is permitted. After amendment from September 1, 1999 which created middle schools, and thus age of finishing school was 16 years old, the changes were dynamic. According to art. 15 par. 2 of the Act on the Educational System (which was binding at that time) "child's education responsibility starts at the time of beginning in a school year of a calendar year which a child becomes 7 years old and lasts until the end of a middle school but not longer than after becoming 18 years old.". Following presented rules, there were crucial changes in the Codes regulations. Prohibition of employment covered persons had not become 16 years old, and graduation from middle school was a condition for employment of an adolescent, but it also had exceptions. ${ }^{28}$ While considering the legal status at that time, an assumption was developed that the Polish legislator intends to pursue the goal set out in Recommendation No. 146 of the International Labor Organization "Members should adopt as their goal a gradual increase of the minimum age for admission to employment or work to 16 years old. ${ }^{229}$ According to mentioned recommendation, Member States obligated themselves to take actions having as a target gradual increase of minimal year that is allowed for taking up a job having by in mind a total liquidation of children's work. In a case of a State that a minimum year for taking up a job is lower than age 15 it is required to take immediate actions leading to increase of that year to age of 15 .

According to a fact that the Act on the Educational System was amended in 2017, among others by changes in art. $2^{30}$, the eight years model of a primary school was again implemented into the system. In that legal aspect, rules that regulate employment of children from Section IX

28 Zbigniew Góral, "O dopuszczalności pracy dzieci w polskim prawie pracy w świetle prawa międzynarodowego i europejskiego," Monitor Prawa Pracy, no. 6 (2004), accessed March 2, 2019, https://czasopisma.beck.pl/monitor-prawa-pracy/artykul/dopuszczalnosci -pracy-dzieci-w-polskim-prawie-pracy-w-swietle-prawa-miedzynarodowego-i-europejskiego/.

29 Góral, "O dopuszczalności pracy dzieci,".

30 Act on the education system of 7 September 1991 Journal of Laws 1991, No. 95, item 425, as amended. 
of the Labour Code had to be amended. In 2019 an amendment was implemented, and it lowered above mentioned threshold from 16 to 15 years of age. Presented change does not lead to performance of the Recommendation No. 146 of the International Labour Organization. Subject matter of the amendment was basing only on the age change. The legislator preserved every standard pointing on prohibition of full time employment of children, permission for light work, and employment on a contract. Notion of an adolescent was extended to an additional year by giving 15 years olds an attribute for taking a job unless primary school was finished.

The Labour Code in art. 22\$2 and $\$ 3$ states that: "\$ 2. Anyone over the age of 18 can be an employee. Under the conditions specified in Section nine, anyone under the age of 18 may also be an employee." Art. $22 \$ 2$ of the Code, in reference to the art. 190 that legislator sends us, states that an employee may be a person that is 18 years old, and also a person that is 15 years old and did not become 18 years old. ${ }^{31}$ Key point condition for employment of an adolescent is also graduation from an eight year primary school as well as presentation of a medical certificate which confirms that the work does not harm an adolescent's health. It is necessary to underline there a distinction between term compulsory schooling and educational obligation. First of them lasts until graduating from a primary school which is in principle until being 15 years old, and second lasts until being 18 years old. ${ }^{32}$

An adolescent may personally come into work relationship but its capability to perform this action was limited by object matter because in principle that person may take up a job but only as a preparation into a profession, and exceptionally to gain earnings basing on employment contract, only for light work and on conditions which allows for performance of educational obligation. An adolescent may be employed full time by an employment contract for preparation into profession, and for gaining earnings only for light work and in time schedule that allows for fulfillment of educational obligation. ${ }^{33}$ Rules of the Labour Code which regulate a perpetual binding time of a contract

31 Ibidem.

32 Arkadiusz Sobczyk, Kodeks pracy. Komentarz (Warsaw: C.H. Beck, 2020), 847.

33 Iwona Anna Wieleba, Zatrudnianie dzieci w celu zarobkowym wedtug polskiego prawa pracy (Lublin: Wydawnictwo Uniwersytetu Marii Curie-Skłodowskiej, 2014), 98-99. 
apply to it, and they are mentioned in the art. 195 and 196 of the Code. Also, it needs to be stressed that contract for employment and contract for preparation into profession are not identical. They differ with an object of the performed work, among others. In the case of a contract for preparation into profession an object is referring to acquirement of qualifications, and for a perpetually binding contract it is a salary and work primarily. ${ }^{34}$ It needs to be pointed that a reference to a perpetually binding agreement implies that adolescents are taken under special protection because that type of a contract is the most stable and the most legally secured in the Polish Legal System. In art. $195 \$ 2$ of the Labour Code we can find a reference to the Minister's Council resolution (in this case it is the resolution of the Ministers Council from 28.05.1996 in reference to preparation of adolescent to work and the rewarding of them) which allows an employer to employ adolescents for own needs to teach them a profession and sign with them a fixed term contract. ${ }^{35}$

When it comes to legal ability to work as a worker that is regulated by the art. $22 \$ 3$ of the Labour Code, an adolescent that, according to the Civil Code has only limited legal capacity, may come into legal relationship with an employee on its own, and without required permission of a legal guardian. To sum up, art. $22 \$ 2$ need to be considered with a link to art. $190 \$ 2$ of the Code, thus working legal capacity has an adolescent that is under the age of 15 years old.

The Code finds exceptions in art. 191 from the mentioned requirement of being 15 years old, and points on three possibilities based on an age and graduation from a primary school.

As a first, a possibility to employ is possible for a person that graduated from a primary school but did not become 15 years old, with limits of the rules for preparation into a profession of adolescents. This limitation does not apply to persons that graduated from an eight years primary school but they are starting their employment in the same calendar year as becoming 15 years old. In that situation they are employed on the rules related to adolescents.

34 Teresa Liszcz, Prawo pracy (Lublin: Wolters Kluwer, 2019), 562.

35 Ordinance of the Council of Ministers of 28 May 1996 Journal of Laws1996, No. 60, item 278, as amended. 
The second possibility covers persons that did not graduate from an eight year primary school and are not 15 years old. The legislator leaves the possibility for employment in order to prepare and teach them a profession, and within the rules that apply to adolescents. Due to fact that it is a specific exception that permits taking a job before graduating from a primary school, it requires certain conditions to be met. Firstly, it may be only if a legal guardian gives a permission, and a psychological clinic gives a positive opinion. Additionally, as an obligatory factor, it is required to get permission of a headmaster of a primary school to perform educational obligation outside of the school, that is located in an area of the employee's living.

We can find in the third group rules to persons that are 15 years old but they did not graduate from a primary school. In this case also a contract for preparation into a profession applies in a form of preparation into a profession, on the proposal of a legal guardian but only if conditions from art. $191 \$ 2(6)$ are met, which are: adoption into a centre that prepares for a profession and is based in a primary school or acquiring headmaster permission to perform an educational obligation outside school, that is located in the area of employee's living. ${ }^{36}$

In case of a person that is 15 years old but did not graduate from a primary school and fulfills educational obligation it is possible to come into an employment contract for preparation into a profession after finishing profession preparation course in a form of preparation into performance of a certain job.

It needs to be stressed the role of a legal guardian which gives consent for that contract, or makes a proposal personally. This is a significant difference in relation to an adolescent that personally makes the mentioned decisions.

Adolescent as an employee may come into working relationships in a matter of acquiring profession preparation. Target of such agreement lays within preparation for future job as a qualified craftsmen or a worker. Professions that are in the scope of that education are mentioned in the National Education Minister's Regulation from November 23, 2011

36 Władysław Patulski and Anna Kamińska-Pietnoczko, "Zatrudnianie młodocianych," in Kodeks pracy. Komentarz, ed. Wojciech Muszalski (Warsaw: C.H. Beck, 2019), 687. 
in the case of classification of professions of vocational schools. ${ }^{37}$ Presently, teaching of a profession lasts from 24 to 36 months. It may come to shortening or lengthening it for no longer than 12 months, and only under certain circumstances which are: pregnancy or a lack of promotion to the next class. The Labour Code protects adolescents and children especially.

According to the art. 200 (1) \$1 "A young person may be employed on the basis of an employment contract to perform light work" ${ }^{38}$ Rules do not define directly the term 'light work', they only point on certain aspects. Further rules mention that employment which is light work cannot collide with fulfilment of the compulsory schooling obligation, and also cannot cause a threat to the childs health. Additionally, no work that is part of forbidden works for adolescents can be considered as a light work. Key point here is a doctor of an occupational medicine who gives permission after evaluation that aligns with the rules from art. 200 (1) of the Code, whether an employer may list in a catalogue of light works a job proposed by his own. Medical diagnosis targets into evaluation whether proposed works are not too heavy for psycho-mental health and development of an adolescent worker.

Preparation for performance of a specific profession is regulated in the $\$ 15$ - 18a of the Ministers Council Regulation from May 281996 relating to professional preparation of adolescents and rewarding of them. ${ }^{39}$ Main goal of this form is to "prepare adolescents to work in a character of a competent worker." ${ }^{40}$ Preparation may last from 3 to 6 months with exception for Voluntary Labour Corps where this time may be extended until graduation from a primary school but not longer than 12 months, and cannot exceed 18 months in total. ${ }^{41}$

37 Ordinance of the Minister of National Education of 23 December 2011, Journal of Laws 2012, item 7.

38 The Labor Code Act of 26 June 1974, Journal of Laws 1974, No. 24, item 141, as amended.

39 Ordinance of the Council of Ministers of 28 May 1996 Journal of Laws 1996, No. 60 , item 278, as amended.

40 Liszcz, Prawo pracy, 566.

41 Ordinance of the Council of Ministers of 28 May 1996 Journal of Laws 1996, No. 60 , item 278 , as amended. 
Art. 200(2) of the Labour Code points also to special working hours of an adolescent. Weekly working hours cannot exceed 12 hours during period of school classes, and they cannot exceed 2 hours daily for a particular day that school classes are present. ${ }^{42}$ In $\$ 3$ of this provision the legislator makes a distinction, namely an adolescent until 16 years old may work maximally 6 hours a day without any exception of exceeding it. Art. 202 $\$ 2$ is an elaboration of that thought because it points that an adolescent until 16 years old may work maximally 8 hours a day.

The Labour Code regulates also in art. 205 vacation leave for adolescents. It is noticed that present legal regime is less favourable for an adolescent than for an adult in a matter of the first vacation leave. After working for 6 months an adolescent gets a right to the first vacation leave in a matter of 12 working days, and after a year of work an adolescent gets 26 days. If that right was acquired before being 18 years old (even if it is in the same calendar year as 18 anniversary) then it comes to limitation of that days to correspond with workers that worked less than 10 years, and it consists of 20 days. In reference to days off in further working years the article sends us to the art. $157 \$ 2$. One specific rule for adolescents' days off is an order for an employer to provide vacation leave during days free from school classes, which are school holidays. According to the art. $205 \$ 4$ of the Labour Code, "The employer is obliged to grant unpaid leave during school holidays at the request of a young person being a student of a school for employees; total leave, together with annual leave, cannot exceed 2 months. The period of unpaid leave is counted into the period of work on which the employee rights are based. ${ }^{33}$ Having in mind the fact that usually adolescents take up a job at the moment of beginning of new semester, and winter holidays are in many times before 6 months of work for them, there were introduced days off in advance, on the basis of the art. $205 \$ 3$, and it bases on providing that day off even before acquiring a right to it. The purpose is to fulfil rules from art. 205 of the Labour Code that refers to employer's responsibility to provide days off for adolescents during school days off. In situation when days off are not used art. 157(1) $\$ 1$ of the Code applies. An employee may

42 Ibidem.

43 The Labor Code Act of 26 June 1974, Journal of Laws 1974, No. 24, item 141, as amended. 
use days off before the end of the contract, and if this does not happen, then according to the Supreme Court Statement from March 292001 , an equivalent is to be paid in accordance to the Labour Code. ${ }^{44}$

\section{CHILD AS AN EMPLOYEE IN THE PRESENT LEGAL REGIME}

After analysis of the provisions of the Labor Code regarding the employment of adolescents, the legal status of the so-called a child in Polish labor law, regulated under art. $304^{5}$ of the Labour Code cannot be omitted. This provision was implemented into the Polish Law due to accession of the Directive 94/33 (EC) from July 22, 1994 relating to protection of adolescents in work on the European level. ${ }^{45}$ Art. $304^{5}$ permits a person to work or to take other gainful activities before being 16 years old but only under strict rules. Firstly, a child can take up a job or other activities for an object that leads cultural, artistic, sports or commercial activity. It is a closed catalogue. Additionally, in contradiction with an adolescent's employment there is needed legal guardian approval. Also, it is under approval of certain bodies that are present in a particular Member State. In the matter of Poland, it is an appropriate job inspector who, after receiving specific application from a subject that a child is going to work for may give permission. In a situation of tasks that cause threat to life, physical health, psycho-mental of a child, or causes threat to fulfillment of school obligation by that child, such inspector rejects the application.

By pointing at cultural, artistic, sport or commercial activity, the legislator distinguished a specific group that definitely did not cause harm to children's health and their psycho-mental growth. It is worth noting by taking into consideration axiological analysis that this approach has been shaped many years before, and during legislative actions related to the La-

44 Polish Supreme Court, Judgment of 29 March 2001, Ref. No. I PKN 336/00, unreported.

45 Directive 94/33 (EC) of 22 July 1994 on the protection of young people at work. Accessed August 3, 2020, http://orka.sejm.gov.pl/Drektywy.nsf/all/31994L0033/\$File/ 31994L0033.pdf. 
bour Law. In 1932 the Convention nr 33 of the International Labour Organization was adopted in Geneva. ${ }^{46}$

In this legal act it was permitted to apply exceptions toward children that are taking part in public spectacles and in production of cinematographic movies, in a character of actors or a supernumerary "with a profit for art, science and education(...)". ${ }^{47}$

Z. Góral in his consideration asks a question "whether performance of work or other gainful activities by children up to 16 years old for subjects that are involved in cultural, artistic, sport or commercial activity may take a form of employment (in a form of the employment contract), or it may only be in a form of a non-employment contract (especially in a form of a civil contract). ${ }^{348}$.

According to I. A. Wieleba, this article refers only to gainful activities basing on civil contracts. ${ }^{49}$ Substantially, this provision should not refer to employment contracts because, according to art. $22 \$ 2$ of the Labour Code such ability to work acquires a person that is 18 years old, and adolescents have this ability but can only take up a job only within the rules in Section IX of the Code. Indeed, article $304^{5}$ of the Labour Code is not presented in this section. The legislator does not categorize activity for a subject that is involved in cultural, artistic, sport or commercial actions as light work..$^{50}$ It comes to a particular age fallacy. This article did not change during amendment, so when age requirement was changed from a threshold of 16 years old. Presently, such ability possesses a person that is 15 years old who is categorised as an adolescent.

As a response to Interpellation $\mathrm{nr} 257799$ in the case of complication of adolescents' employment, due to a lack of amendment of implementing

46 Polish Supreme Court, Judgment of 29 March 2001, Ref. No. I PKN 336/00, unreported.

47 International Labor Organization, Convention No 33, on the age of admission of children to work in non-industrial professions. Accessed April 13, 2019, http:/www.mop.pl/ $\mathrm{doc} / \mathrm{html} /$ konwencje/k033.html.

48 Góral, "O dopuszczalności pracy dzieci,".

49 Wieleba, Zatrudnianie dzieci, 101.

50 Góral, "O dopuszczalności pracy dzieci,”. 
regulations after changes in the Labour Code ${ }^{51}$ among others, art. 190 and $304^{5}$ of the Code have different character in the matter of performed activity. An adolescent, according to art. 190 does not perform a gainful job but acquires knowledge and skills in profession, and a child that performs different gainful job basing on the art. $304^{5}$ does a regular job. Additionally, an adolescent performs a preparation for a profession on the basis of the Section IX of the Labour Code, therefore the legislator points that full protection of rights was created, and which regulates employment of adolescents. In the case of children below 16 years old this argumentation is unequivocal- they perform a work on the basis of civil contracts and the Civil Code does not set any protection of that group, therefore a permission from an appropriate labour inspector allows for settlement of conditions of employment with an object that runs artistic, cultural, sport or commercial activity. Mentioned solution is then, the instrument for children's protection.

There needs to be paid attention to the fact that there is a lack of consequences in the legislator actions. Although art. 190 of the Labour Code sets a person that is 15 years old as an adolescent, and allows that person to make their own decisions about possible employment, then during regulation of a working time in art. $202 \$ 2$ it divides adolescents on a group of 15-16 years old, and over 16 years old. It needs to be asked a question in this moment- why adolescents were divided for older and younger? Acquiring knowledge and professional skills is desirable for all adolescents. Also, all of them attend on school classes while acquiring education to their professions. Why then, only persons that are 16 years old are taken under legal protection by the State?

Additionally, independence of an adolescent that is 15 years old in aspect of the ability to work are strengthened by art. $191 \$ 2(1)-2(7)$ in a situation when employment is upon decision of a legal guardian because some requirements were not met.

51 Response to interpellation No. 25779 on complications in employing minors, incl. due to the lack of amendments to executive regulations following changes to the Labor Code. Accessed August 23, 2020, http://www.sejm.gov.pl/-Sejm8.nsf/InterpelacjaTresc .xsp?key=B55HRK. 


\section{ADOLESCENT'S AND CHILDREN'S EMPLOYMENT IN THE NATIONAL LABOUR INSPECTORATE REPORTS}

When looking for the answer on the question why in practice art. 190 and $304^{5}$ of the Labour Code established two different age limits, it is worth checking annual reports of the Main Labour Inspector working in the National Labour Inspectorate that are available on their webpage. In reference to the Amendment of the Labour Code Act in 2004 when art. $304^{5}$ was implemented, competences of the Inspectorate were extended because it became a body that gives and removes permissions for performance of certain jobs by children until being 16 years old which is essential to perform a job stated in the article. There were 124 applications considered, 119 permissions were given and for 5 cases applications were rejected. ${ }^{52}$ The effect of the Amended Code finds its place also in reports of the Inspectorate, because since 2004 there is no topic for adolescents' employment. Crucial attention is given to applications considerations. Unfortunately, there are no statistics for adolescents' work.

The 2005 report provides statistics only for applications to perform gainful activities by children up to 16 years old, analogically to the previous report. The amount of noted applications increased to 424 where 417 of them were approved and 7 rejected. ${ }^{53}$ Applications were referring mostly to employment during rehearsals, theatre and opera performances, rarer for commercial and movie plays. ${ }^{54}$

In the 2006 report, it was stated that there were 245 applications for employment of a child up to 16 years old, but after running a control check there were 398 of them, and 392 of which were approved and 6 rejected $^{55}$; in 2007 there were 201 applications, and after the National Labour Inspec-

52 Chief Labor Inspector's report on the activities of the National Labor Inspectorate - 2004. Accessed May 19, 2019, http://www.bip.pip.gov.pl/pl/bip/px_spr_gip_04_ rozdz_03.pdf, 34.

53 Chief Labor Inspector's report on the activities of the National Labor Inspectorate 2005. Accessed May 19, 2019, https://www.pip.gov.pl/pl/f/v/34002/spr\%2005\%2004a.pdf, 33.

54 Ibidem.

55 Chief Labor Inspector's report on the activities of the National Labor Inspectorate 2008. Accessed May 19, 2019, https://www.pip.gov.pl/pl/f/v/33044/s\%2008\%2002.pdf, 25. 
torate investigations there were 376 approvals, ${ }^{56}$ then in 2008 there were 214 applications noted and 464 approvals given by the Inspectorate. ${ }^{57}$

The 2008 report content covers a summary section that mentions obeying the Labour Law rules in reference to adolescents. According to the mentioned data, the Inspectorate ran 726 controls of employers who employ adolescents. ${ }^{58}$ Amount of working adolescents was estimated at 3914, whereas employers that had been taken under control, were employing 25 thousand workers in total. Major breaches were noted in the topic of the lack of permitted jobs schedule for adolescents for profession preparation- 43\% examined. It points to an increase in comparison to 2007 where that amount was 36\%. ${ }^{59} 29 \%$ of employers that had been controlled did not run time sheets for permitted jobs in a matter of preparation to an profession. ${ }^{60}$ It was claimed that many times adolescents have not been taken under proper preparation which employer must provide in the matter of: missing preliminary medical examination- 437, and also 566 cases for missing medical certificate confirming work's lack of harmful impact on development and safety of an adolescent (they were noted in $22 \%$ of controlled employers); lack of preliminary training- 256 adolescents (13\% of employers). ${ }^{61}$ To sum up, the Inspectorate claimed that mentioned breaches for most of the time are coming from ignorance and rarer, from negligence. It was also said that some of employers are doing it consciously to reduce costs. Although 4 years passed, the Inspectorate's remark about

56 Chief Labor Inspector's report on the activities of the National Labor Inspectorate - 2004-2007. Accessed May 19, 2019, https://www.pip.gov.pl/pl/f/v/33660/spr\%20 07-rozdz2.pdf, 21.

57 Chief Labor Inspector's report on the activities of the National Labor Inspectorate 2008. Accessed May 19, 2019, https://www.pip.gov.pl/pl/f/v/33044/s\%2008\%2002.pdf, 25.

58 Chief Labor Inspector's report on the activities of the National Labor Inspectorate - 2007. Accessed May 19, 2019, https://www.pip.gov.pl/pl/f/v/33660/spr\%20 07-rozdz2.pdf, 21.

59 Chief Labor Inspector's report on the activities of the National Labor Inspectorate 2008. Accessed May 19, 2019, https://www.pip.gov.pl/pl/f/v/33044/s\%2008\%2002.pdf, 25.

60 Chief Labor Inspector's report on the activities of the National Labor Inspectorate 2008. Accessed May 19, 2019, https://www.pip.gov.pl/pl/f/v/33044/s\%2008\%2002.pdf, 79.

61 Ibidem. 
the lack of proper implementation of the Labour Code rules from Section IX did not change and points at lowering adolescents salary. ${ }^{62}$

What is interesting, is the fact that in the 2009 report the Inspectorate once again returned to presentation of statistics for providing applications for children's work up to 16 years old without mentioning adolescents. It stems from the presented data that 178 applications were noted which covered 547 children, 543 of which were approved and only 4 rejected. ${ }^{63}$ The same scheme was presented for the 2010 report where the amount of applications was noted for 271 , and referring to 682 children. There were 9 rejections and all others were approved. ${ }^{64}$

The reports for 2011,2012 and 2013 are built within the same scheme by mentioning only the topic of applications. According to data, there were 270 applications which covered 755 children, and all of them were approved in the year $2011^{65}, 518$ of which 824 permissions for work were given and 1 rejection provided in the year 2012, ${ }^{66} 292$ applications for work permission of which 732 permissions were given and one rejection noted. ${ }^{67}$

The 2014 report covered the greatest amount of approved permissions for work for children up to 16 years old. There were 1482 applications, and 2246 decisions on that basis- 2238 were positive. ${ }^{68}$ Unfortunately, this

62 Ibidem.

${ }_{63}$ Chief Labor Inspector's report on the activities of the National Labor Inspectorate 2009. Accessed May 19, 2019, https://www.pip.gov.pl/pl/f/v/32622/r02.pdf, 30.

${ }^{64}$ Chief Labor Inspector's report on the activities of the National Labor Inspectorate 2010. Accessed May 19, 2019, https://www.pip.gov.pl/pl/f/v/32579/r02.pdf, 32.

65 Chief Labor Inspector's report on the activities of the National Labor Inspectorate 2011. Accessed May 20, 2019, https://www.pip.gov.pl/pl/f/v/32576/sprawozdanie\%20 2011.pdf\%20\#page= 17,31 .

${ }^{66}$ Chief Labor Inspector's report on the activities of the National Labor Inspectorate - 2012. Accessed May 20, 2019, https://www.pip.gov.pl/pl/f/v/32530/d\%2002\%20 dzialalnosc\%20kontrolna\%20i\%20prewencyjna\%20informacje\%20ogolne.pdf, 32 .

67 Chief Labor Inspector's report on the activities of the National Labor Inspectorate 2013. Accessed May 20, 2019, https://www.pip.gov.pl/pl/f/v/100996/sprawozdanie2013. pdf\#page $=13,30$.

${ }_{68}$ Chief Labor Inspector's report on the activities of the National Labor Inspectorate 2014. Accessed May 20, 2019, https://www.pip.gov.pl/pl/f/v/133794/sprawozdanie\%20 2014.pdf\#page=13, 29 . 
is the last of the Inspectorate's reports which clearly, and with specific distinction of this rules provide data about adolescents' and children's work.

There is noticed a shift in presented data area performed by the Inspectorate as well as increase of children's work up to 16 years old. Probably it may be an effect of rising social awareness. In reference to adolescents a significant problem is a lack of obedience of rules from Section IX of the Labour Code due to high costs and no economic profits.

It seems that we acquired almost utopian argumentation towards protection of children up to 16 years old due to lack of that protection by the law, and by treating adolescents as a fairly safe group at the same time. Above mentioned reports give a signal that adolescent's employment is full of negligence and breaches.

There can be also found in data from reports about children's work, and precisely speaking amount of permissions given for that work. What about inspection of that work? As a response to interpellation there was given an argument that art. $304^{5}$ is absolutely justified and fair because it guarantees a control by the Inspectorate. What is more, it is required for that wording of the article because there are no other legal rules that would guarantee a protection. It needs to be asked the question then, whether solutions that are present right now are sufficient? Why the State is not providing reports? How a parent, who is to decide whether his child should take up a particular job, should have a certainty that the State provides his child protection in the working environment?

In presented reports a tendency for breaches in reference to adolescents' employment increases proportionally to permissions for children's work. However, no mechanism for combating of this event appeared. At the same time, the change for adolescents age gives only greater opportunity to employers for more breaches and negligence, because they are to work with even younger humans, less conscious and less developed mentally and physically in many cases.

\section{CONCLUSIONS}

To settle the presented doubts, there needs to be noted in the first place the purpose that Poland sets as a target when implementing Recom- 
mendations No. 146 of the International Labour Organization: 'Members should set as their goal gradual increase of minimum year that is permitted for work to 16 years old.' ${ }^{69}$ The amendment lowering age to 15 certainly does not lead to realization of this assumption.

There cannot be skipped in this place the international definition of a child that was implemented in our State and which states that a child is every person up to 18 years old. ${ }^{70} \mathrm{~A}$ question arises in this contextwhy the legislator led to privileging children up to 16 years old through the Labour Code rules form? Why, by creation a term of an adolescent that covers persons between 15 and 18 years old the legislator also in this place gives greater privileges and additional protection to adolescents up to 16 years old by permission for 8 hours work daily, just the same as for an adult. Certainly, one of the first answers would be referring to the Constitution and more precisely, to art. 65 par. 3 which prohibits permanent employment for children up to 16 years of age. Then, what is the status of persons that are 16 years old- are they employees who, due to their maturity do not need additional protection?

Undoubtedly, the Constitutional Tribunal is right for claiming that: "welfare of the child" is a core of all rules towards children rights. It is the instrument for existing rules interpretation but also a directive towards new law creation and its application. It is also a criterion for evaluation of decisions related to children and settlement of colliding interests of a child and other entities, parents especially. " However, was the welfare always taken into consideration during creation of the present norms?

First of all, there needs to be set a reference to adolescents' diversity by removing provisions that sets 16 years old as less privileged group that should work longer. These persons are still a part of adolescents group, and do not acquire an adult status and are still children, according to the presented definition. Adolescents, no matter if 15 or 16 years old during taking up a job learning a profession still attend to school during that time. Limited amount of hours is for protection of their psycho-mental health,

69 Góral, “O dopuszczalności pracy dzieci,”.

70 United Nations General Assembly Convention on the Rights of the Child of 20 November 1989 Journal of Laws 1991, No. 120, item 526.

71 Por. Baum and Stojanowska, Wtadza rodzicielska, 32. 
reduction of overload, and for giving them a possibility to attend to school which also requires a preparation. This is established in art. 197 of the Labour Code which obliges an adolescent to educate. There is no justification then, for that distinction.

In reference to art. $304^{5}$ there needs to be claimed that leaving an age of 16 years old is completely incomprehensible because it creates collisions in the practice. In the present legal status, it comes to an event which can be characterized as a double legal subjectivity of a 15 years old human. One person acquires at the same age the ability to work and is treated as an adolescent, basing on art. 190 of the Code, and according to art. $304^{5}$ that person is still a child who requires a legal guardian for making a decision. Explanation of that, although based on protection of a child argumentation, does not trigger that in the presented practice. There need to be made an amendment of the rule by implementation of an age of 15 years old. An additional desirable step is a change to the type of agreements that children are coming into by their legal guardians. Because the Code does not protect children during their work a hybrid concept of civil agreements with additional instruments of child protection should be withdrawn. It needs to be implemented that contracts with children are regular employment contracts and rules from the Section IX do apply.

De lege lata needs to control adolescent work through established bodies for that purpose, to limit potential negative consequences for their health by performed work.

To sum up, rules related to adolescent's work are set in andifferent section of the Labour Code, which is Section IX. This fact points to a special protection of children's work in the Polish Law, which stems above all, from the Constitution and International Legal Acts such as the Children Rights Convention or International Labour Organization conventions. Rules that apply to children's work characterise more severe surveillance and requirements for safety. All aspects that are regulated by rules are for creation of total protection against exploitation, exhaustion, and for fulfillment of educational obligation. However, the last amendment raises a lot of doubts and questions that needs to be further investigated by the legislator for more efficient protection of a worker below 18 years of age, which is presented now. 


\section{REFERENCES}

Baum, Mirosław, and Wanda Stojanowska. Wtadza rodzicielska pozamatżeńskiego i rozwiedzionego ojca. Studium socjologiczno-prawne. Warsaw: Akademia Pedagogiki Specjalnej im. Marii Grzegorzewskiej, 2000.

Góral, Zbigniew. "O dopuszczalności pracy dzieci w polskim prawie pracy w świetle prawa międzynarodowego i europejskiego.” Monitor Prawa Pracy, no. 6 (2004): 151-155. Accessed March 2, 2019. https://czasopisma.beck.pl/ monitor-prawa-pracy/artykul/dopuszczalnosci-pracy-dzieci-w-polskim-prawie-pracy-w-swietle-prawa-miedzynarodowego-i-europejskiego/.

Lachowski, Stanisław. Praca dzieci wiejskich a ich rozwój fizyczny i stan zdrowia. Lublin: IMW, 1999.

Liszcz, Teresa. Prawo pracy. Lublin: Wolters Kluwer, 2019.

Morawska, Elżbieta Hanna. "Ochrona praw dziecka w świetle art. 72 Konstytucji RP: uwagi na tle orzecznictwa Trybunału Konstytucyjnego." Kwartalnik Prawa Publicznego 7, no. 4 (2007): 127-132.

Patulski, Władysław, and Anna Kamińska-Pietnoczko. "Zatrudnianie młodocianych." In Kodeks pracy. Komentarz, edited by Wojciech Muszalski, 685-708. Warsaw: C.H. Beck, 2019.

Sobczyk, Arkadiusz. Kodeks pracy. Komentarz. Warsaw: C.H. Beck, 2020.

Stadniczeńko, Stanisław. "Ochrona praw dziecka wynikająca z art. 19 Konwencji o prawach dziecka oraz art. 72 Konstytucji RP.” Zeszyty Naukowe Państwowej Wyższej Szkoty Zawodowej im. Witelona w Legnicy, no. 22(1) (2017): 16.

Wieleba, Iwona Anna. Zatrudnianie dzieci w celu zarobkowym wedtug polskiego prawa pracy. Lublin: Wydawnictwo Uniwersytetu Marii Curie-Skłodowskiej, 2014.

Winczorek, Piotr. Komentarz do Konstytucji RP z dnia 2 kwietnia 1997 r. Warsaw: Liber, 2000. 
